\title{
OPTIMIZATION OF ADDITIONAL COMPOSITION VARIATIONS ZnO NANOPARTICLES ON THE CHARACTERISTICS OF POOR HYDROXYPATITE AS BONE FILLER
}

\author{
Fardatul Azkiyah ${ }^{1, a)}$, Djony Izak Rudyardjo ${ }^{1}, \operatorname{Jan} \mathrm{Ady}^{1}$ \\ ${ }^{1}$ Department of Physics Faculty of Science and Technology \\ Universitas Airlangga, Surabaya, Jawa Timur, Indonesia \\ ${ }^{a}$ Email : farda.azkiyah@gmail.com \\ Article History \\ Received : August 2021, Revised : October 2021, Accepted : October 2021, Online : December 2021
}

\begin{abstract}
Research on the synthesis and characterization of porous hydroxyapatite with the addition of $\mathrm{ZnO}$ nanoparticles has been carried out through a combination of foam immersion and injection methods. This research was conducted to optimize the previous research by increasing the variation of $\mathrm{ZnO}$ composition and adding the injection method to the research process. The materials used in this research include hydroxyapatite nanoparticles, $\mathrm{ZnO}$ nanoparticles, Aquades, PVA and polyurethane foam. Manufacturing is done by immersing polyurethane foam into a slurry. Slurry is a mixture of PVA and hydroxyapatite solutions with variations in the addition of $\mathrm{ZnO}$ nanoparticles $(8 \mathrm{wt} \%, 10 \mathrm{wt} \%, 12 \mathrm{wt} \%$, and $14 \mathrm{wt} \%)$. Then inject the remaining slurry into the foam. After that the sample was dried and heated at a temperature of $650^{\circ} \mathrm{C}$ to remove foam and PVA, then the sample was sintered at a temperature of $1200^{\circ} \mathrm{C}$ for 3 hours. Based on SEM analysis, porosity test, and compressive strength test, the best results were shown by sample IV because it had a pore diameter of $142.9-371.4 \mathrm{~m}$ with a porosity of $69.983 \%$, a compressive strength value of $1.8653 \mathrm{MPa}$ and non-toxic. The best results have not met the standard for bone filler application. In further research, improvements need to be made by using other additives such as $\mathrm{ZrO}^{2}$, so that it can improve the mechanical properties of porous hydroxyapatite to meet standard bone filler applications. Keywords: Porous hydroxyapatite, $\mathrm{ZnO}$ nanoparticles, PVA, Polyurethane foam, Bone filler.
\end{abstract}

\section{INTRODUCTION}

Bone filler demands will increase every year. This is caused by diseases that affect bone damage such as bone cancer (osteosarcoma). Bone cancer (osteosarcoma) is caused by bone malfunctioning cells or uncontrolled cell growth. Based on data published by the American Cancer Society (2014), cases of osteosarcoma mostly occur in children and young adults between the ages of 10 to 30 years. Handling cases of osteosarcoma can now be done by giving chemotherapy and surgery (Kawiyana, 2009). Surgical treatment is done by cutting the part of the bone affected by cancer and then connecting it to the bone from the donor. The limited number of organ donors at this time, resulted in the treatment of bone cancer (osteosarcoma) is done with a surgical process, then performed a transplant with a new biomaterial whose structure and function is similar to bone.

Biomaterials are defined as materials used to replace body parts or functions in a safe, economic and physiologically acceptable value (Park et al, 2007). Biomaterials are widely used for bone substitution due to bone tissue damage. The requirements that must be met by biomaterials for bone substitution are biocompatibility, bioactivity, osteoconductive, non-toxic, non-corrosive, proper design and can integrate quickly. One of the biomaterials that can be applied to fill damaged bone cavities is bone filler. This bone filler will disappear when the growth of new bone cells has occurred (Nurmanta, 2013). Characteristics of bone filler that need to be considered as a bone filling material include porosity, pore diameter size, and mechanical properties in the form of compressive strength. The porosity of bone filler required by bone is $\pm 70 \%$ (Keaveny, 2004). The most suitable pore size for bone cell growth is in the range of 100-400 $\mathrm{m}$ (Swain, 2009).

A better candidate of bone filler is the one that has a structure and composition similar to natural bone. Hydroxyapatite - $\mathrm{ZnO}$ nanoparticle composite can be used as a bone filler material. This is because hydroxyapatite 
has a structure and composition similar to bone, but has low mechanics properties. The improvement of the mechanical properties can be done by adding $\mathrm{ZnO}$ nanoparticles as bone strengthening additives. $\mathrm{ZnO}$ nanoparticles are modern ceramics that are bioactive and can help the cell growth process. The compressive strength of the bone will increase with the addition of $\mathrm{ZnO}$ and the porosity decreases with the addition of $\mathrm{ZnO}$ (Syamsuddin, 2010).

In Yunita's research (2014), porous hydroxyapatite was made by adding $\mathrm{ZnO}$ nanoparticles through polymer foam immersion and then followed by a sintering process. From this study, the resulting porous hydroxyapatite with good porosity and pore size values, but the resulting comprjessive strength value is not suitable and is still far from the compressive strength value required by bone. The compressive strength value of bone filler required for bone is 7.5 - $41 \mathrm{MPa}$ (Ylinen, 2006).

Based on this background, in this research optimization was carried out by adding $\mathrm{ZnO}$ nanoparticle additives at a certain concentration and by adding an injection method to make the foam immersion method more effective. The above efforts were made to improve the quality of the resulting bone filler and to improve the densification process along the grain boundaries so as to improve the mechanical properties of the bone filler. Thus, the resulting bone filler is expected to meet medical application standards. The parameters for porous hydroxyapatite such as pore size, porosity, compressive strength, bonding groups, and toxic effects in this study can be observed through several tests, namely SEM - EDX test, porosity test, compressive strength test, FTIR test, and MTT assay test.

\section{EXPERIMENTAL METHOD}

This research started from the stage of making hydroxyapatite slurry with variations in the addition of $\mathrm{ZnO}$ nanoparticles of $8 \mathrm{wt} \%, 10 \mathrm{wt} \%, 12 \mathrm{wt} \%$, and $14 \mathrm{wt} \%$. Hydroxyapatite slurry is a mixture of hydroxyapatite nanoparticles, $\mathrm{ZnO}$ nanoparticles, PVA, and Aquades. Then proceed with the process of immersion and injection of polyurethane foam measuring $1 \mathrm{~cm} \times 1 \mathrm{~cm} \times 1 \mathrm{~cm}$ with a hydroxyapatite slurry. After that the sample was dried and heated at a temperature of $80^{\circ} \mathrm{C}$ and $650^{\circ} \mathrm{C}$ to remove foam and PVA, then the sample was sintered at a temperature of $1200^{\circ} \mathrm{C}$ for 3 hours.

Furthermore, the resulting porous hydroxyapatite will be characterized to determine the characteristics of porous hydroxyapatite which will later be applied as bone filler. The characterization includes SEM - EDX test, porosity test, compressive strength test, FTIR test, and MTT assay test. The SEM - EDX test was carried out to determine the microstructure and the value of $\mathrm{Ca}: \mathrm{P}$ in the sample, while the porosity test was carried out to determine the amount of porosity in the sample. The compressive strength test was carried out to determine the ability of the sample to withstand the load and the FT-IR test was carried out to determine the functional group of a sample. The MTT assay test was used to determine the toxic nature of the sample.

\section{RESULT AND DISCUSSION}

The results of the synthesis of hydroxyapatite with the addition of $\mathrm{ZnO}$ nanoparticles in this study are shown in Figure 1.

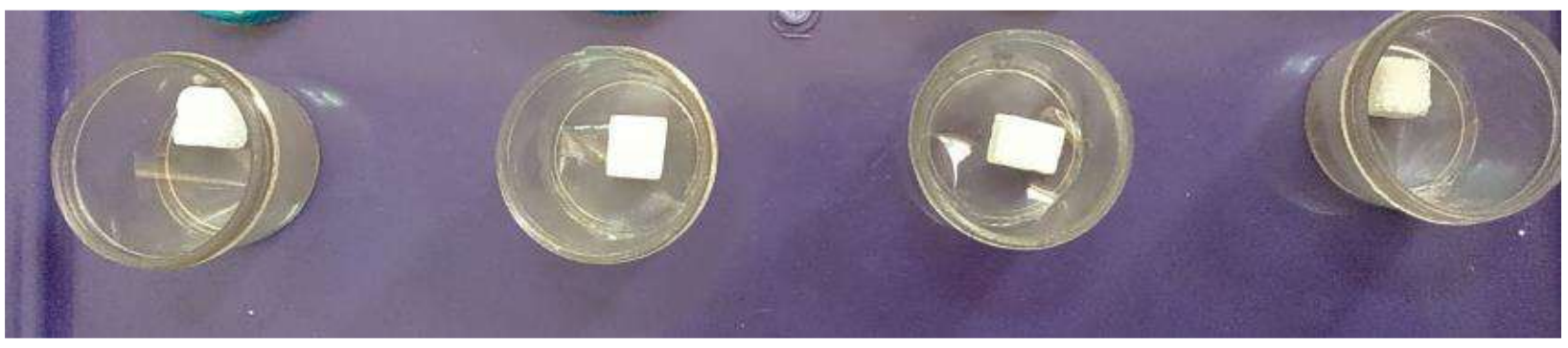

FIGURE 1. Porous hydroxyapatite sample with variations in the addition of $\mathrm{ZnO}$ nanoparticles of $8 \mathrm{wt} \%, 10 \mathrm{wt} \%$, $12 \mathrm{wt} \%$, and $14 \mathrm{wt} \%$

From the four samples produced, then carried out several characterization tests including SEM-EDX test, porosity test, compressive strength test, FTIR test and MTT assay test. 


\section{FTIR Result}

The FTIR test was carried out to identify the functional groups present in the sample. The main purpose of this FTIR test is to prove that the PVA and Polyurethane foam functional groups have disappeared due to the sintering process. The results of the FTIR test of porous hydroxyapatite samples with variations in the addition of $\mathrm{ZnO}$ nanoparticles are shown in Figure 2 and Figure 3.
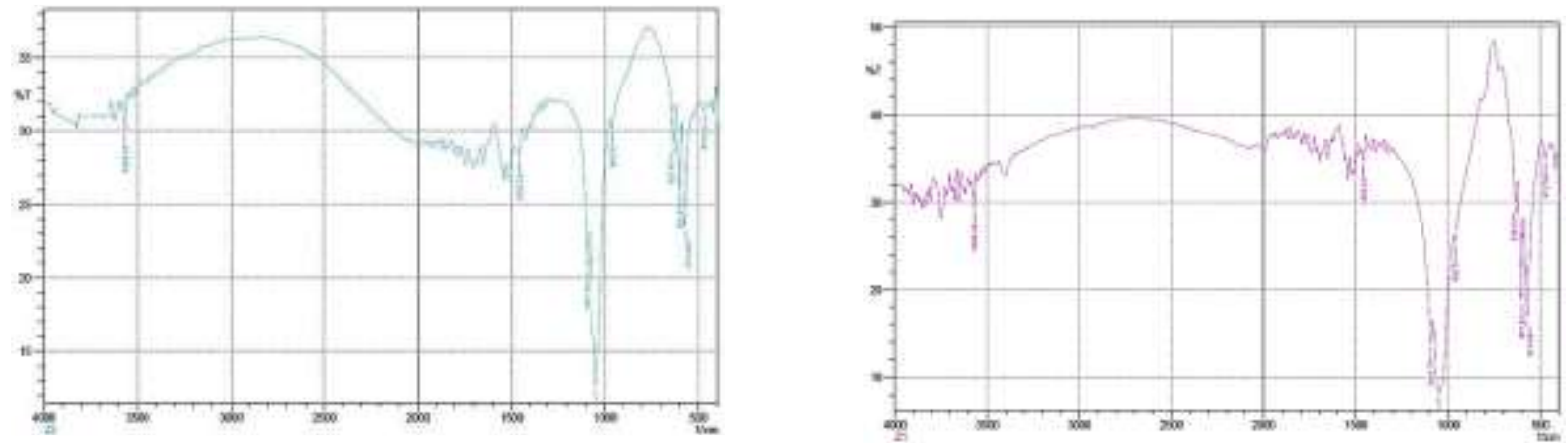

FIGURE 2. FTIR test results of porous hydroxyapatite samples with variations in the addition of $\mathrm{ZnO}$ nanoparticles of 8 wt $\%$ and $10 \mathrm{wt} \%$.
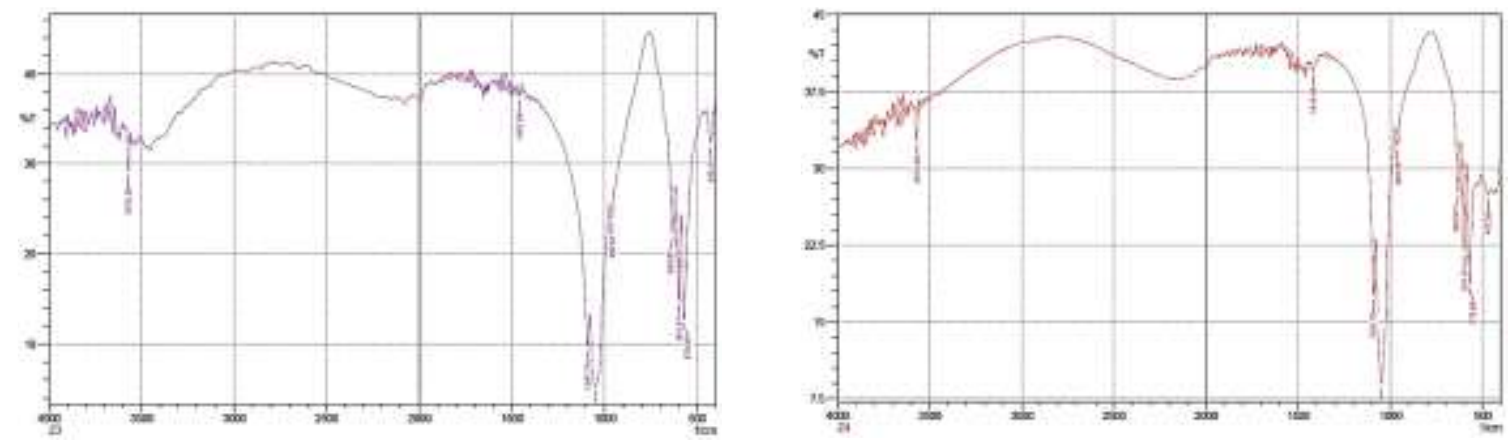

FIGURE 3. FTIR test results of porous hydroxyapatite samples with variations in the addition of ZnO nanoparticles of 12 $\mathrm{wt} \%$ and $14 \mathrm{wt} \%$.

The graph of the FTIR test results in the Figure above can be analyzed by comparing the absorption bands formed in the infrared spectrum using the spectrum of a known comparison compound (reference). The results and wavenumber analysis of porous hydroxyapatite samples with variations in the addition of $\mathrm{ZnO}$ nanoparticles are presented in Table 1 below.

TABLE 1. The results of the wave number on the FTIR test of porous hydroxyapatite samples with variations in the addition of certain $\mathrm{ZnO}$ nanoparticles.

Wave numbers (cm-1)

\begin{tabular}{cccc}
\hline & & \multicolumn{2}{c}{ Vibration Type } \\
\hline Sampel I & Sampel II & Sampel III & Sampel IV \\
\hline 472.58 & 470.65 & 428.21 & 472.58 \\
570.95 & 570.95 & 570.95 & 570.95 \\
601.81 & 601.81 & 601.81 & 601.81 \\
636.53 & 632.67 & 632.67 & 632.67 \\
962.51 & 962.51 & 962.51 & 960.58 \\
1049.31 & 1051.24 & 1049.31 & 1051.24 \\
1091.75 & 1091.75 & 1091.75 & 1091.75 \\
1458.23 & 1458.23 & 1462.09 & 1419.66 \\
3568.43 & 3568.43 & 3572.29 & 3570.36
\end{tabular}

\section{Functional groups}

And
PO43- simetri bending

PO43- asimetri bending

PO43- asimetri bending

OH- ion stretching

PO43- simetri stretching

PO43- asimetri stretching

PO43- asimetri stretching

CO32- asimetri stretching

OH- ion stretching 
Based on the FTIR spectrum analysis described in Table 1 above, the four samples only contained a phosphate group $\left(\mathrm{PO}_{4}{ }^{3-}\right)$, a carbonate group $\left(\mathrm{CO}_{3}{ }^{2-}\right)$ and an $\mathrm{OH}$ group only. In the FTIR spectrum analysis, no new groups were found, this indicates that mixing hydroxyapatite with $\mathrm{ZnO}$ nanoparticles is only physical mixing, so there is no chemical bond between hydroxyapatite and $\mathrm{ZnO}$ nanoparticles. This also proves that the presence of the PVA functional group and polyurethane foam has been lost due to the heating and sintering process. If the sample still contains PVA and polyurethane, then the FTIR spectrum will show peaks of the PVA and polyurethane groups listed in Table 2 and Table 3.

\begin{tabular}{lc} 
TABLE 2. Wave Number of PVA (polyvinyl alcohol) Functional Groups \\
\hline Fuctional group & Wave number (cm-1) \\
\hline C-C & $1450-1600$ \\
C-H & $2800-3000$ \\
O-H & $3000-3700$ \\
\hline
\end{tabular}

TABLE 3. Wave Number of Polyurethane Foam Functional Groups

\begin{tabular}{ll}
\hline Functional group & Wave number $(\mathbf{c m - 1})$ \\
\hline O-H & $3000-3700$ \\
C-H & $2800-3000$ \\
Ester & $1735-1750$ \\
& $1300-1420$ \\
C-C & $1450-1600$ \\
C-O & $900-1300$ \\
$840-790$ & \\
\hline
\end{tabular}

\section{SEM-EDX Result}

The SEM test was conducted to determine the surface structure and pore diameter of each sample, while the EDX test was conducted to determine the elements or minerals contained in the porous hydroxyapatite sample. The results of the SEM test in the form of a porous hydroxyapatite microstructure are shown in Figure 4 and Figure 5.

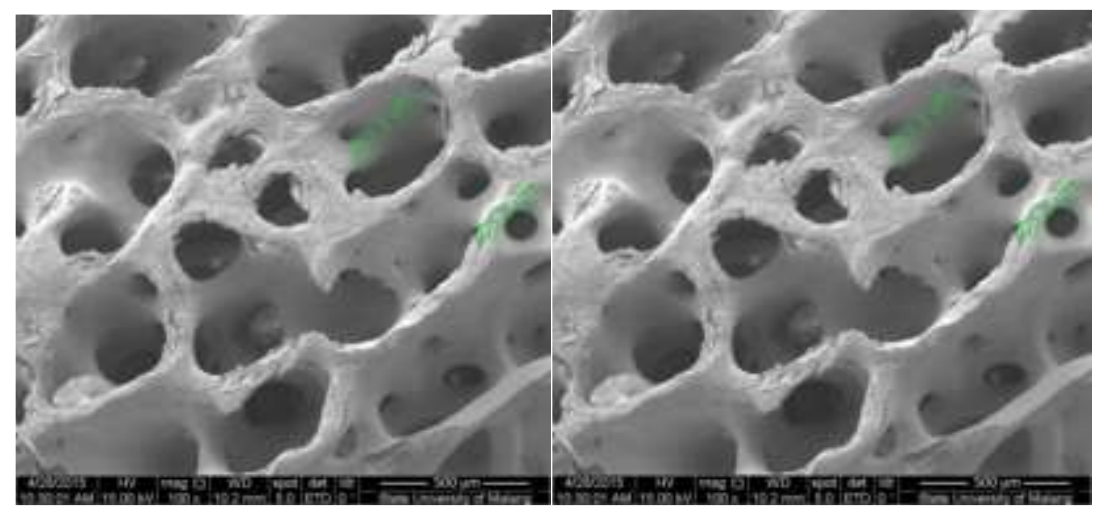

FIGURE 4. SEM test results of porous hydroxyapatite samples with variations in the addition of $\mathrm{ZnO}$ nanoparticles of 8 $\mathrm{wt} \%$ and $10 \mathrm{wt} \%$.

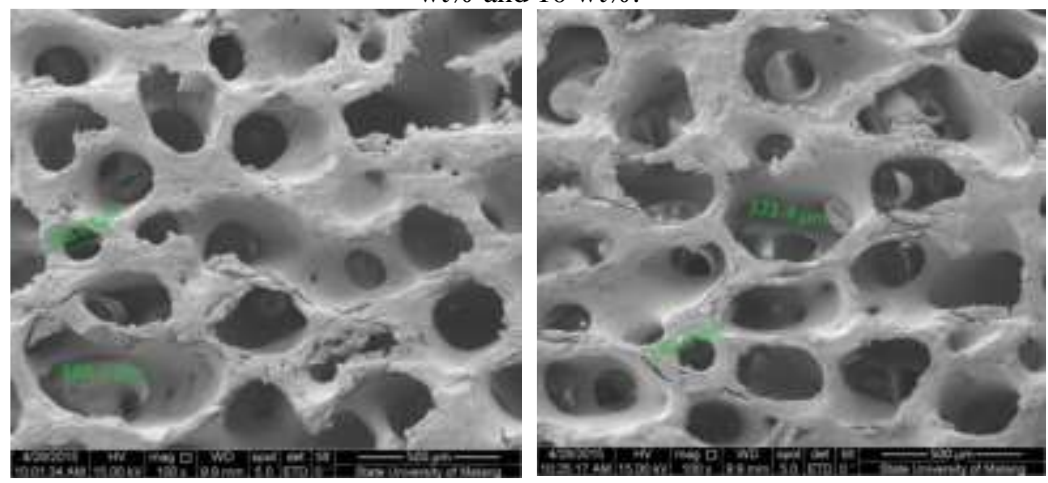

FIGURE 5. SEM test results of porous hydroxyapatite samples with variations in the addition of $\mathrm{ZnO}$ nanoparticles of 12 wt $\%$ and $14 \mathrm{wt} \%$. 
Figure 4 and Figure 5 above show that the addition of $\mathrm{ZnO}$ nanoparticles affects the pore size of the porous hydroxyapatite sample. The effect of the addition of $\mathrm{ZnO}$ nanoparticles on the pore diameter size of hydroxyapatite samples can be shown in Table 4.

TABLE 4. Results of pore diameter measurements of porous hydroxyapatite samples with variations in the addition of certain $\mathrm{ZnO}$ nanoparticles.

\begin{tabular}{ccccc}
\hline & \multicolumn{2}{c}{ Parameter } & \multicolumn{2}{c}{ Additional ZnONPs } \\
\cline { 2 - 5 } & Sampel I & Sampel II & Sampel III & Sampel IV \\
8 wt \% & $\mathbf{1 0 ~ w t \% ~}$ & $\mathbf{1 2}$ wt\% & $\mathbf{1 4}$ wt\% \\
\cline { 2 - 5 } Pore diameter & $105.8-457.1 \mu \mathrm{m}$ & $114.3-428.6 \mu \mathrm{m}$ & $128.6-385.7 \mu \mathrm{m}$ & $142.9-371.4 \mu \mathrm{m}$ \\
\hline
\end{tabular}

Table 4 shows that the size of the pore diameter in the porous hydroxyapatite samples decreased according to the increase in the number of additions of $\mathrm{ZnO}$ nanoparticles. This happens because $\mathrm{ZnO}$ nanoparticles can increase the densification process along the grain boundary reinforcement and can fill the empty space in the sample, so that the more $\mathrm{ZnO}$ nanoparticles are added, the pore size in the sample decreases. The results of this SEM test showed that the pore diameter sizes for samples III and IV had met the effective bone filler pore diameter size for bone growth, which was 100-400 m. The best pore diameter results were obtained by sample IV with a size of $142.9-371.4 \mathrm{~m}$. These results are in accordance with the parameters of the pore diameter of bone filler which is effective for bone cell growth.

The results of the EDX test can be shown as Figure 6 and Figure 7 below.
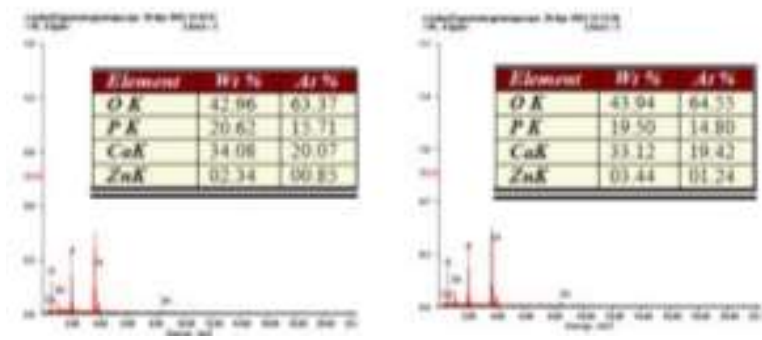

FIGURE 6. EDX test results from porous hydroxyapatite samples with variations in the addition of $\mathrm{ZnO}$ nanoparticles of 8 $\mathrm{wt} \%$ and $10 \mathrm{wt} \%$.
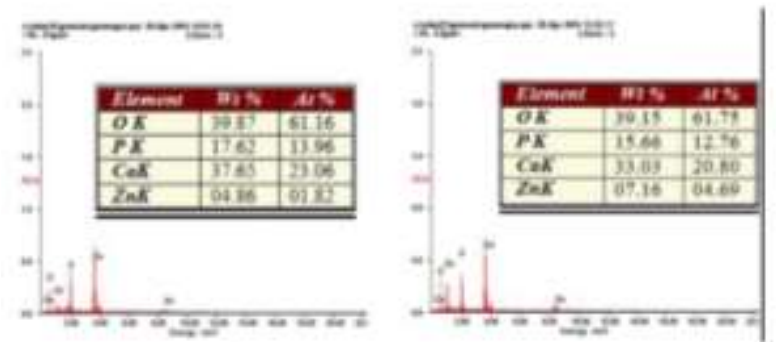

FIGURE 7. EDX test results from porous hydroxyapatite samples with variations in the addition of $\mathrm{ZnO}$ nanoparticles of 12 wt $\%$ and $14 \mathrm{wt} \%$.

The results of the EDX test were used to determine the ratio of $\mathrm{Ca} / \mathrm{P}$ in porous hydroxyapatite samples. The analysis of the $\mathrm{Ca} / \mathrm{P}$ ratio of hydroxyapatite samples for variations in the composition of the addition of $\mathrm{ZnO}$ nanoparticles additives can be presented in Table 5 .

TABLE 5. Ca/P ratio results from porous hydroxyapatite samples with variations in the addition of $\mathrm{ZnO}$ nanoparticles 8 $\mathrm{wt} \%, 10 \mathrm{wt} \%, 12 \mathrm{wt} \%$, and $14 \mathrm{wt} \%$.

\begin{tabular}{ccccc}
\hline & \multicolumn{2}{c}{ Parameter } & \multicolumn{2}{c}{ Additional ZnONPs } \\
\cline { 2 - 5 } & $\begin{array}{c}\text { Sampel I } \\
\mathbf{8} \mathbf{w t} \%\end{array}$ & $\begin{array}{c}\text { Sampel II } \\
\mathbf{1 0} \mathbf{w t} \%\end{array}$ & $\begin{array}{c}\text { Sampel III } \\
\mathbf{1 2} \mathbf{w t} \%\end{array}$ & $\begin{array}{c}\text { Sampel IV } \\
\mathbf{1 4} \mathbf{~ w t \%}\end{array}$ \\
\cline { 2 - 5 } Rasio Ca/P & 1.28 & 1.31 & 1.65 & 1.63 \\
\hline
\end{tabular}

Analysis of the results of the $\mathrm{Ca} / \mathrm{P}$ ratio in the EDX test for the four samples had a $\mathrm{Ca} / \mathrm{P}$ value of less than 1.67. This is due to the presence of $\mathrm{Zn} 2+$ cations which partially substitute $\mathrm{Ca} 2+$ cations in hydroxyapatite $\left(\mathrm{Ca}_{10}\left(\mathrm{PO}_{4}\right) 6(\mathrm{OH})_{2}\right)$. This is in accordance with research conducted by Gross et al (2013), that $10 \%$ mol of $\mathrm{Zn}$ 
(Zinc) can only substitute $3 \% \mathrm{~mol}$ of $\mathrm{Ca}$ (calcium). The addition of $\mathrm{ZnO}$ to pure hydroxyapatite causes the reaction described in the following equation.

$$
\mathrm{Ca}_{10}\left(\mathrm{PO}_{4}\right) 6(\mathrm{OH})_{2}+x \mathrm{ZnO} \mathrm{Ca} a_{10-\mathrm{zn}} \mathrm{Zn}_{\mathrm{x}}(\mathrm{PO} 4) 6(\mathrm{OH})_{2}+\mathrm{y} \mathrm{H}
$$

The addition of Zinc Oxide to pure hydroxyapatite will produce an alloy of $\mathrm{Zn}-\mathrm{HA}$ and $\mathrm{H}_{2} \mathrm{O}$. Meanwhile, $\mathrm{H} 2 \mathrm{O}$ is lost due to the sintering process in the process of making porous hydroxyapatite. This replacement of calcium by $\mathrm{Zn}$ resulted in the value of the $\mathrm{Ca} / \mathrm{P}$ ratio being lower than the $\mathrm{Ca} / \mathrm{P}$ ratio of pure hydroxyapatite. This is because the formation of $\mathrm{Ca}(\mathrm{Zn})$ has decreased the number of calcium atoms. While the $\mathrm{Zn}$ atom is not able to replace the $\mathrm{Ca}$ (calcium) atom completely (Miyaji et al., 2005).

\section{Porosity Test}

Porosity testing is carried out to calculate the percentage of the volume of free space contained in the sample. The results of the porosity testing of porous hydroxyapatite samples with variations in the addition of $\mathrm{ZnO}$ nanoparticles $8 \mathrm{wt} \%, 10 \mathrm{wt} \%, 12 \mathrm{wt} \%$, and $14 \mathrm{wt} \%$ are shown in Table 6 below.

TABLE 6. The results of porosity testing of porous hydroxyapatite samples with variations in the addition of $\mathrm{ZnO}$ nanoparticles $8 \mathrm{wt} \%, 10 \mathrm{wt} \%, 12 \mathrm{wt} \%$, and $14 \mathrm{wt} \%$.

\begin{tabular}{lllll}
\hline & \multicolumn{2}{c}{ Parameter } & \multicolumn{3}{c}{ Additional ZnONPs } \\
\cline { 2 - 5 } & Sampel I & Sampel II & Sampel III & Sampel IV \\
& $\mathbf{8 w t} \%$ & $\mathbf{1 0}$ wt\% & $\mathbf{1 2} \mathbf{w t \%}$ & $\mathbf{1 4} \mathbf{w t \%}$ \\
\cline { 2 - 5 } Porositas (\%) & 73.548 & 73.397 & 71.169 & 69.983 \\
\hline
\end{tabular}

Based on Table 6 above, different porous hydroxyapatite porosity results were obtained along with the addition of different $\mathrm{ZnO}$ nanoparticles. The effect of the addition of $\mathrm{ZnO}$ nanoparticles on the porosity of porous hydroxyapatite samples is shown in Figure 8.

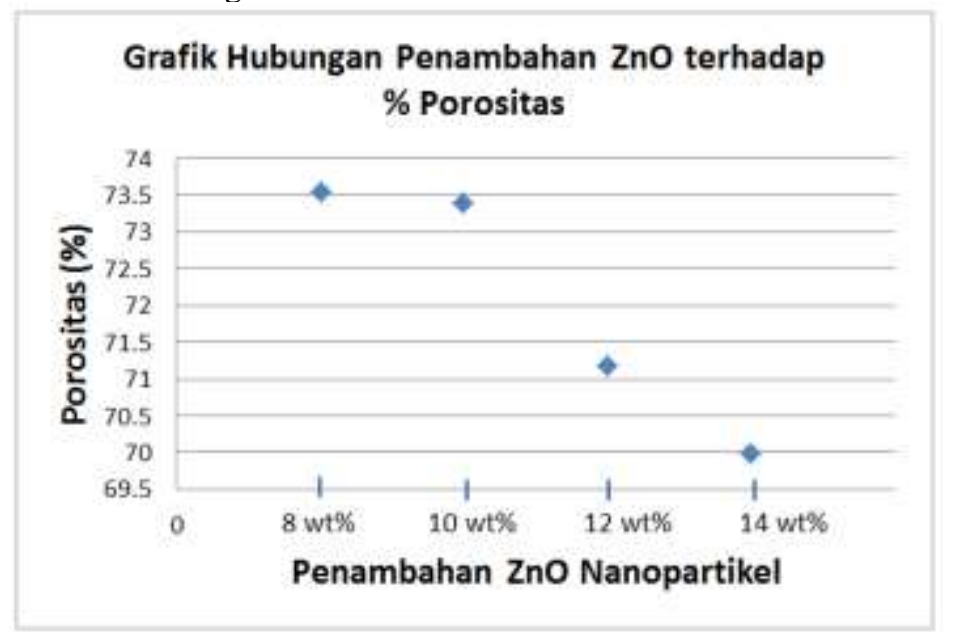

FIGURE 8. Graph of the relationship between the addition of $\mathrm{ZnO}$ nanoparticles with the porosity of the porous hydroxyapatite sample.

Based on Figure 8 above, it was found that the porosity value of the sample decreased with the addition of $\mathrm{ZnO}$ nanoparticles. This is because the addition of $\mathrm{ZnO}$ concentration can increase the densification process along the grain boundary strengthening so as to reduce the porosity value (Syamsuddin, 2010). This decrease in the porosity value causes an increase in the pore density and mechanical properties of the sample. The pore size can be controlled by the polyurethane foam framework. The heating process at $650^{\circ} \mathrm{C}$ and the sintering process at $1200^{\circ} \mathrm{C}$ resulted in the loss of PVA and polyurethane foam. On the other hand, the foam cavity left by the polyurethane will be occupied by $\mathrm{ZnO}$ nanoparticles which can increase the densification process along the grain boundary reinforcement.

According to Keaveny (2004), porous hydroxyapatite to be applied as a bone filler to the spongious femur requires a porosity of $\pm 70 \%$. In this study, the porosity values of the four samples were $73.548 \%, 73.397 \%$, $71.169 \%$, and $69.983 \%$ for samples I, II, III, and IV. From these results it is known that the porosity value for all samples is in accordance with the existing literature, but the best porosity value is owned by sample IV, which is 
$69.983 \%$. This shows that the porosity in sample IV meets the effective porosity standard of \pm 70 , so it can be applied as bone filler.

\section{Compressive Strength Test}

The compressive strength test is carried out to find out how strong the sample is to withstand a load. This test is also a benchmark for materials that can be used as bone fillers, if the material is too brittle, it will not be strong enough to support the body's weight. The results of the compressive strength test of porous hydroxyapatite samples with variations in the addition of $\mathrm{ZnO}$ nanoparticles $8 \mathrm{wt} \%, 10 \mathrm{wt} \%, 12 \mathrm{wt} \%$, and $14 \mathrm{wt} \%$ can be seen in Table 7 below.

TABLE 7. The results of the compressive strength test of porous hydroxyapatite with variations in the addition of $\mathrm{ZnO}$ nanoparticles $8 \mathrm{wt} \%, 10 \mathrm{wt} \%, 12 \mathrm{wt} \%$, and $14 \mathrm{wt} \%$.

\begin{tabular}{ccccc}
\hline & \multicolumn{2}{c}{ Parameter } & \multicolumn{2}{c}{ Additional ZnONPs } \\
\cline { 2 - 5 } $\begin{array}{c}\text { Sampel I } \\
\mathbf{8} \mathbf{w t} \%\end{array}$ & $\begin{array}{c}\text { Sampel II } \\
\mathbf{1 0} \mathbf{w t} \%\end{array}$ & $\begin{array}{c}\text { Sampel III } \\
\mathbf{1 2} \mathbf{w t} \%\end{array}$ & $\begin{array}{c}\text { Sampel IV } \\
\mathbf{1 4} \mathbf{w t} \%\end{array}$ \\
\cline { 2 - 5 } $\begin{array}{c}\text { Compressive } \\
\text { Strength (MPa) }\end{array}$ & 1.6033 & 1.6808 & 1.7713 & 1.8653 \\
\hline
\end{tabular}

Based on the results obtained in Table 7, the compressive strength values are different for the four samples. From the table above, a graph of the relationship between variations in the composition of the addition of $\mathrm{ZnO}$ nanoparticles on the mechanical properties of compressive strength of porous hydroxyapatite samples is obtained as shown in Figure 9 below.

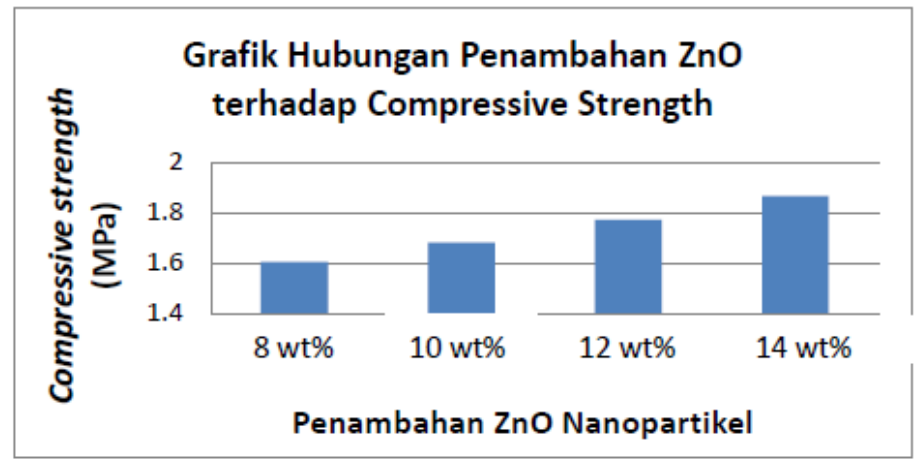

FIGURE 9. Graph of the relationship between variations in the addition of $\mathrm{ZnO}$ nanoparticles with the compressive strength of porous hydroxyapatite samples.

Based on the graph in Figure 9, it is found that the addition of $\mathrm{ZnO}$ nanoparticles in the manufacture of hydroxyapatite samples can increase the compressive strength of the sample. This is because $\mathrm{ZnO}$ is a biodegradable material for the body and has good mechanical properties. The combination of $\mathrm{ZnO}$ as an additive with hydroxyapatite using the sintering method is a way to improve the mechanical properties of the sample. The compressive strength increases with the addition of $\mathrm{ZnO}$ concentration (Syamsuddin, 2010).

According to Ylinen (2006), spongious bone has a compressive strength value of $7.5-41 \mathrm{MPa}$. In this study, sample IV, hydroxyapatite with the addition of $\mathrm{ZnO}$ nanoparticles of $14 \mathrm{wt} \%$ had the best compression test results, namely the compressive strength value of $1.8653 \mathrm{MPa}$. This compressive strength value is much greater than the previous study by Yunita (2014) which used the immersion method with the composition of the addition of $\mathrm{ZnO}$ nanoparticles of $7 \mathrm{wt} \%$ which was $0.319 \mathrm{MPa}$. The addition of $\mathrm{ZnO}$ additives is useful for increasing densification along grain boundary reinforcement and the use of nano-sized powders for a better densification contribution (Swain, 2009). This is evident from the increasing percentage of $\mathrm{ZnO}$ nanoparticles added, the more compressing the empty spaces of hydroxyapatite, so that the addition of $\mathrm{ZnO}$ nanoparticles to porous hydroxyapatite can improve the mechanical quality of bone filler. In addition, the combination of immersion and injection methods can increase the value of the resulting compressive strength. The injection method is used to streamline the diffusion of the hydroxyapatite slurry solution to more easily enter the pores of the polyurethane foam. In this process an external force is applied in the form of injection injection pressure to enter the hydroxyapatite slurry solution. This is done so that the hydroxyapatite slurry is more easily interstitial into the pores of the polyurethane foam. 
In this study, the compressive strength values for the four porous hydroxyapatite samples with the addition of $\mathrm{ZnO}$ nanoparticles did not meet the standard compressive strength values required by bone. This is because the pores are located irregularly, not homogeneously and not interconnected with each other (not sticky), so that it becomes a factor that weakens the strength.

The presence of porosity can also affect the value of compressive strength in the sample. The higher the level of porosity of the bioceramic, the lower the value of the compressive strength of a sample, in this case the bone filler will be more brittle (Kalita, 2006). The effect of the magnitude of the porosity on the compressive strength of the sample is shown by the graph in Figure 10.

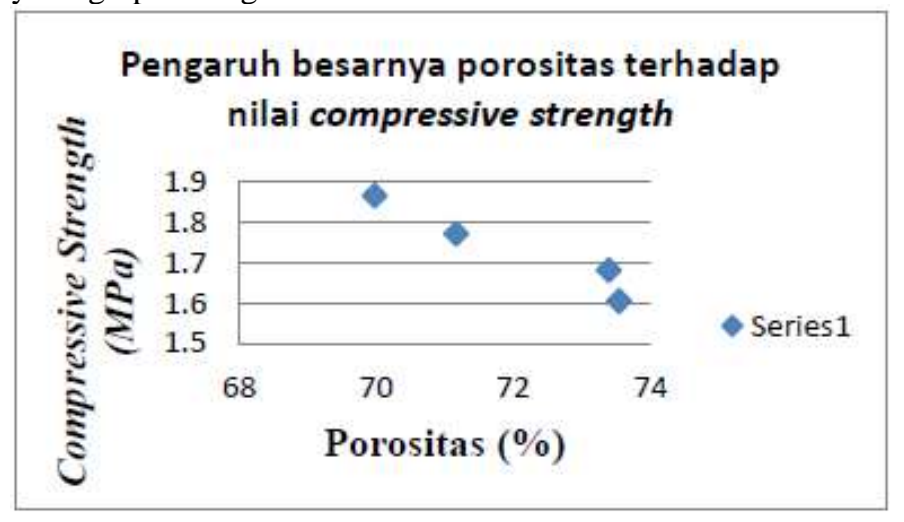

FIGURE 10. Graph of the relationship between the effect of the magnitude of the value of porosity (\%) with the value of compressive strength $(\mathrm{MPa})$ of porous hydroxyapatite samples.

\section{MTT Assay Test}

The MTT assay test was conducted to prove that the porous hydroxyapatite sample was non-toxic so that it could be applied as a bone filler. The results of the MTT assay in the form of percentage of living cells from porous hydroxyapatite samples with variations in the addition of $\mathrm{ZnO}$ nanoparticles $8 \mathrm{wt} \%, 10 \mathrm{wt} \%, 12 \mathrm{wt} \%$, and $14 \mathrm{wt} \%$ are shown in Table 12 below.

TABLE 12. MTT assay test results for porous hydroxyapatite samples with variations in the addition of $\mathrm{ZnO}$ nanoparticles 8 $\mathrm{wt} \%, 10 \mathrm{wt} \%, 12 \mathrm{wt} \%$, and $14 \mathrm{wt} \%$

\begin{tabular}{ccccc}
\hline & \multicolumn{2}{c}{ Parameter } & \multicolumn{2}{c}{ Additional ZnONPs } \\
\cline { 2 - 5 } & $\begin{array}{c}\text { Sampel I } \\
\mathbf{8} \mathbf{~ w t \%}\end{array}$ & $\begin{array}{c}\text { Sampel II } \\
\mathbf{1 0} \mathbf{w t} \%\end{array}$ & $\begin{array}{c}\text { Sampel III } \\
\mathbf{1 2} \mathbf{w t} \%\end{array}$ & $\begin{array}{c}\text { Sampel IV } \\
\mathbf{1 4} \mathbf{~ w t} \%\end{array}$ \\
\cline { 2 - 5 } $\begin{array}{c}\text { \% Sel hidup } \\
\text { (OD) }\end{array}$ & $99.97 \%$ & $64.36 \%$ & $79.57 \%$ & $65.50 \%$ \\
\hline
\end{tabular}

Based on Table 12 above, the results of the calculation of the optical density value of each sample tested using the MTT assay were obtained. Optical density is a material for absorbing light. The value of optical density (OD) is equivalent to the number of living cells. The higher the OD value, the more viable cells. An OD value of more than $60 \%$ indicates that the sample is non-toxic. Based on the results of the MTT assay as shown in Table 12 above, it was found that the four porous hydroxyapatite samples were non-toxic. This is evidenced by the OD value of more than $60 \%$.

The four porous hydroxyapatite samples were not toxic because during the sintering process, PVA and polyurethane were removed so that only hydroxyapatite and $\mathrm{ZnO}$ remained. This is also supported by testing FTIR for the four samples that do not contain functional groups belonging to PVA and Polyurethane foam. The FTIR test results prove that PVA and Polyurethane foam have been successfully removed by heating at $650^{\circ} \mathrm{C}$ and sintering at $1200^{\circ} \mathrm{C}$ for 3 hours.

\section{CONCLUSION}

The more $\mathrm{ZnO}$ nanoparticles are added, the pore size and porosity of the sample will decrease, while the compressive strength of the sample will increase. Sample IV with a pore diameter of $142.9-371.4 \mathrm{~m}$, a porosity value of $69.983 \%$, a compressive strength value of $1.8653 \mathrm{MPa}$ and non-toxic has the potential to be applied as bone filler because these results meet the effective pore diameter size for bone cells growth (100-400 $\mathrm{m})$ and the effective porosity value is $\pm 70 \%$. 


\section{REFERENCES}

1. American Cancer Society. 2014. Osteosarcoma. American Journal. Atlanta : American Cancer Society, nationwide voluntary organization.

2. Gross, K.A., et al., 2013, Efficient Zinc Incorporation in hydroxyapatite through Crystallization of Amorphous Phase could Extend the Properties of Zinc Apatites, Institute of Biomaterials and Biomechanics, Riga Technical University, Latvia.

3. Kalita, S., et al., 2006, Fabrication of 3-D Porous Mg/Zn doped Tricalcium Phosphate Bone-Scaffolds via the Fused Deposition Modelling, Department of Mechanical, Materials and Aerospace Engineering, University of Central Florida, Orlando, Florida.

4. Kawiyana, Siki. 2009. Osteosarkoma : Diagnosis dan Penanganannya. Sub Bagian / SMF Orthopedi dan Traumatologi. Bagian Bedah FK Unud. RSUP Sanglah Denpasar.

5. Keaveny, Tony M., Morgan, Elise., 2004, Standard Handbook of Biomedical Engineering and Design, Mechanic of Human Body : Chapter 8 Bone Mechanic. New York : McGraw Hill.

6. Miyaji, Fumiaki., Kono, Yoshiteru., Suyama, Kono., 2005. Formation and Structure of Zinc - Substituted Calcium Hydroxyapatite. Department of Material Science, Faculty of Science and Engineering. Shimane University, Japan.

7. Nurmanta, Dica Aprilia, 2013. Optimalisasi Parameter Proses Sintering pada Pembuatan Biokeramik Hidroksiapatit Makropori untuk Aplikasi Bone Filler pada Kasus Kanker Tulang (Osteosarcoma), Skripsi, Departemen Fisika, Fakultas Sains dan Teknologi, Universitas Airlangga, Surabaya.

8. Park, Joon B., Bronzino, Joseph D. 2007. Biomaterials : Principles and Applicationan Introduction, 3rd Edition, New York: CRC Press.

9. 14

10. Swain, S. K., 2009, Processing of Porous Hydroxyapatite Scaffold, Thesis, Department of Ceramic Engineering, National Institute of Technology, Rourkela.

11. Syamsuddin, 2010. Analisis Uji Tekan dan Porositas Material Kompaksi Sinter HA/ZnO sebagai Material Substitusi Tulang, Tesis Rekayasa Biomedis, Universitas Gadjah Mada, Yogyakarta. .

12. Ylinen, P., 2006, Applications of Coralline Hydroxyapatite with Bioabsorbable Containment and Reinforcement as Bone Graft Substitute, Academic Dissertation, Department of Orthopaedics and Traumatology, Helsinki University Central Hospital and University of Helsinki, Helsinki.

13. Yunita, Erma. 2014. Pengaruh Penambahan ZnO Nanopartikel terhadap Karakteristik Bone Filler Hidroksiapatit Berpori, Skripsi. Departemen Fisika, Fakultas Sains dan Teknologi, Universitas Airlangga, Surabaya. 